\title{
Fungal and Bacterial Co-Infection of Sea Bass (Dicentrarchus labrax, Linnaeus 1758) in a Recirculating Aquaculture System: Saprolegnia parasitica and Aeromonas hydrophila
}

\author{
Ezgi Dinçtürk ${ }^{1}$ (D), Tevfik Tansel Tanrıkul' ${ }^{1}$ (D), Saniye Türk Çulha² (1)
}

Cite this article as: Dinçtürk, E., Tanrıkul, T.T., Türk Çulha, S. (2018). Fungal and Bacterial Co-Infection of Sea Bass (Dicentrarchus labrax, Linnaeus 1758) in a Recirculating Aquaculture System: Saprolegnia parasitica and Aeromonas hydrophila. Aquatic Sciences and Engineering, 33(3): 67-71.

'Department of Aquaculture, Izmir Katip Çelebi University, Faculty of Fisheries, İzmir, Turkey

${ }^{2}$ Department of Basic Sciences, İzmir Katip Çelebi University, Faculty of Fisheries, İzmir, Turkey

Submitted:

25.10.2017

Accepted:

26.03.2018

Correspondence:

Ezgi Dinçtürk

E-mail:

ezgi.dincturk@ikc.edu.tr

(C) Copyright 2018 by Aquatic

Sciences and Engineering

Available online at

dergipark.gov.tr/tjas

\begin{abstract}
Aeromonas hydrophila causes symptoms of hemorrhagic septicemia in acute cases and can cause death in freshwater fish, whereas Saprolegnia parasitica is the cause of ulcers complicated by fungal mycelia located on skin that has lost its scales for various reasons. Both pathogens co-infect recirculating aquaculture systems at the İzmir Katip Çelebi University Fisheries Research and Training Center. Clinical, bacteriological, parasitological, and mycological studies were carried out on 25 fish samples during the infestation. Sabouraud glucose agar and malt extract agar were used to isolate the fungus, and the bacterial isolates were streaked on tryptic soy agar (Oxoid) with 5\% defibrinated sheep blood. Gray-white cotton-like patches, erosions on the skin, and hemorrhaging were detected on the infected fish samples. The analytical profile index test and molecular identification showed that the bacterial agent was $A$. hydrophila and a fungal examination and amplification by polymerase chain reaction confirmed that the mycotic agent was $S$. parasitica.
\end{abstract}

Keywords: Aeromonas hydrophila, Dicentrarchus labrax, Saprolegnia parasitica

\section{INTRODUCTION}

Aeromonas hydrophila is an opportunistic microorganism that is widely distributed in water, soil and food (Laith and Najiah, 2013). It is a Gram-negative motile bacterium with aerobic and facultative anaerobic, oxidase-positive characteristics and can be found in aquatic environments and gastrointestinal tracts of healthy fish (Rey et al., 2009; Laith and Najiah, 2013). It is known as Bacterial Hemorrhagic Septicemia, Aeromonad Septicemia and Red Pest (Roberts and Shepherd, 2001) the major symptoms of which are skin ulcers, hemorrhaging and necrosis of visceral organs (Huizinga et al., 1979; Austin and Austin, 2007; Cipriano et al., 2001). A. hydrophila has a great impact on fish farms causing outbreaks with a mortality rate of $80-100 \%$ in a short period of time (Lukistyowati, 2012; Kusdarwati et al., 2017). To date the pathogen has been reported in various fish species such as mirror carp and gold fish (Timur, 1986), rainbow trout (Diler and Al- tun, 1995), guppy (Timur et al., 2003) and xiphophorus (Akayli and Zeybek, 2005) caught in Turkey.

Saprolegniasis is a mycotic freshwater disease that especially, affects fish and eggs (Gaikowski et al., 2003). It usually starts with cotton woollike patches on the head and dorsal fin region then spreads all over the body as focal patches (Abdel-Aziz et al., 2002; Bangyakkum et al., 2003; Osman et al., 2008; Roberts, 2012). Erosion, poor water quality, overcrowding, handling, malnutrition, spawning or bacterial and parasitic infections may be the cause of this mycotic disease and it can lead to mortality (Noga, 1993; Pickering, 1994; Hussien et al., 2010). In Turkey, Saprolegniosis has, generally, been reported in freshwater fish species, especially in rainbow trout eggs (Diler, 1992).

Co-infections are described as infections caused by two or more genetically different pathogens and each pathogen has pathogenic 
effects that cause harm to the host when other pathogens are present (Cox, 2001; Bakaletz, 2004; Kotob et al., 2016). Interactions between different pathogens can have either synergistic or antagonistic effects on fish. Aeromonas hydrophila and Saprolegnia parasitica were detected in sea bass (Dicentrarchus labrax) with high mortalities and clinical signs of both pathogens in this study.

\section{MATERIAL AND METHOD}

Infected sea bass (D.labrax) with fungal infections and hemorrhages on different parts of the body were found in the university pond at Izmir Katip Çelebi University Fisheries Research and Training Center. Fish weighing approximately 40 gr were examined during the infestation and mortalities with water parameters were observed. 25 of the samples were subjected to clinical, microbiological, parasitological and pathological examination. An external and internal examination was carried out on the skin, abdomen, fins, gills, kidneys, intestines, liver and spleen. Bacterial examinations were conducted according to Austin and Austin (2007). Bacterial isolates were streaked on Tryptic Soy Agar (TSA, Oxoid; Merck, Germany) and Tryptic Soy Agar supplemented with $5 \%$ defibrinated sheep blood (BTSA) from the anterior of the kidneys, spleen and liver of the fish.

Fungal samples were provided from the patches on the body surfaces and streaked on Sabouraud Glucose Agar (SGA, Oxoid; Merck, Germany) and Malt Extract Agar (MEA, Oxoid; Merck, Germany). The bacterial samples were incubated at $21^{\circ} \mathrm{C}$ for 2 days and fungal samples were incubated at $21^{\circ} \mathrm{C}$ for $3-4$ days. Native and colored samples were examined with a light microscope (BX53; Olympus, Japan) after incubation. Colorization of the fungus samples was conducted according to Arda (2006).

A scanning electron microscopic examination was carried out at İzmir Katip Çelebi University's Central Research Laboratory and for preparation, samples were sputtered with gold by QUORUM Q150 RES (Quorum Technologies, UK) and examined with a scanning electron microscope (Carl Zeiss 300VP, Germany).

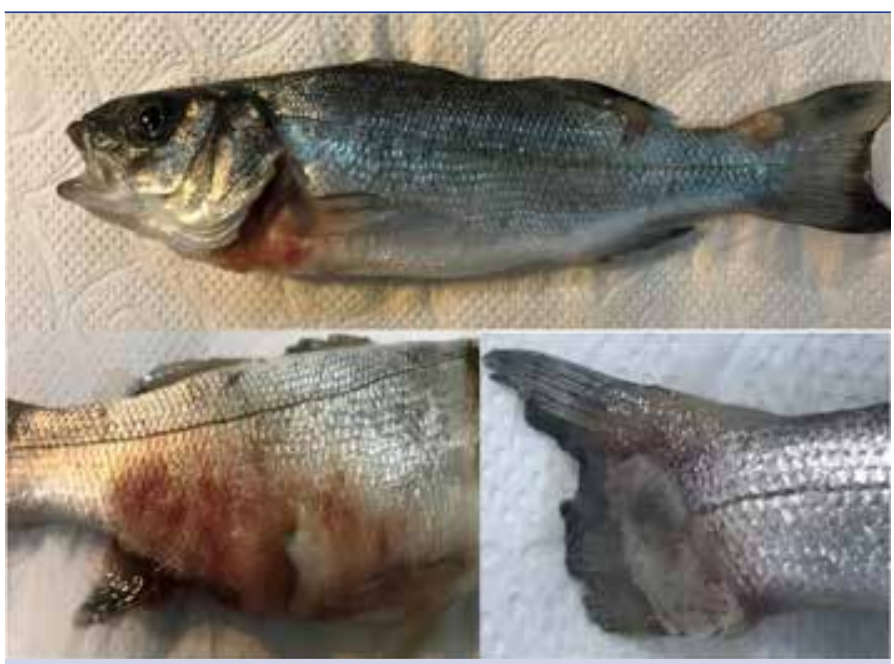

Figure 1. Hemorrhagic septicemia and fungal growth on sea bass (D.labrax)
Aeromonas hydrophila strains were passaged onto TSA and BTSA three times in order to purify the colonies after primer isolation. They were then cultivated onto TSA for biochemical tests. Gram staining and an oxidase test were carried out according to standard procedures. The motility of the bacteria was detected by the hanging-drop technique. For further information, biochemical tests were carried out with API 20E (BioMerieux S.A., France) (Tanrıkul et al., 2004).

Molecular identification of the bacteria and fungus were conducted. The 16SrRNA gene sequence was polymeraze chain reaction (PCR) amplified in order to ensure that strains were A.hydrophila. Strains were obtained from the samples that were isolated from infected D.labrax during the outbreak. A EurX GeneMATRIX Tissue Bacteria DNA Isolation Kit (EURx, Poland) was used for DNA isolation. Then with a Thermo Scientific Nanodrop 2000 (ThermoFisher Scientific, USA), the density and quality of the isolates were determined. 27F and 1492R primers were used for PCR amplifications. Band screening of the PCR products was observed in the gel electrophoresis. Amplified products of template DNA were sent to the Macrogen direct sequencing service (Macrogen, Holland) for sequence determination. Sequences were thenchecked with the BLASTN 2.6.1. database. The Same procedure was used for fungus samples. DNA isolation was conducted using a EurX Tissue Bacteria DNA isolation kit. For PCR amplification, ITS1 and ITS4 primers were used and DNA samples were sent to Macrogen direct sequencing service (Macrogen, Holland) and sequences were checked with the BLASTN 2.6.1. database.

The antibiotic susceptibility of $A$. hydrophila strains was determined by the Kirby-Bauer disk diffusion method onto MuellerHinton medium (Hudzicki, 2009).

The water parameters such as temperature, salinity, oxygen and $\mathrm{pH}$ parameters were determined as $10^{\circ} \mathrm{C}, 3.93 \%, 10.07 \mathrm{mg} / \mathrm{L}$ and 7.7 , respectively. The suspended solid matter was analyzed with gravimetric methods (Stirling, 1985). Analyses of ammonium nitrogen, nitrite nitrogen, nitrate nitrogen, phosphate phosphorus, silica and chlorophyll-a were performed using a Spectrophotometer (DR 6000 Hach LANGE; Germany) (Strickl and Parsons, 1972; Parsons et. al., 1984; Stirling, 1985). Alkalinity, Ca and Mg were analyzed according to Egemen and Sunlu, (2003).

\section{RESULT AND DISCUSSION}

Stunned swimming, loss of balance and appetite were observed during the outbreak. Grey-white cotton like patches, erosion on skin and hemorrhages were shown on the infected fish samples. Mycelial growth and hemorrhages were observed on the fins and body surface (Figure 1).

Aeromonas hydrophila was isolated from the internal organs of sea bass with bacteriological studies from all the fish samples. Gram staining of the bacteria was shown in Figure 2. API test and molecular identification were also conducted (Figure 2, Table 1) with similar results.

The PCR amplification of the A. hydrophila gene sequence was registered in the BLASTN 2.6.1 database. It resulted in 100\% nucleotide identity between the current isolate and $A$. hydrophila (accession number MF445123.1). 
The antibiotic susceptibility test results are shown in Figure 3 and Table 2.

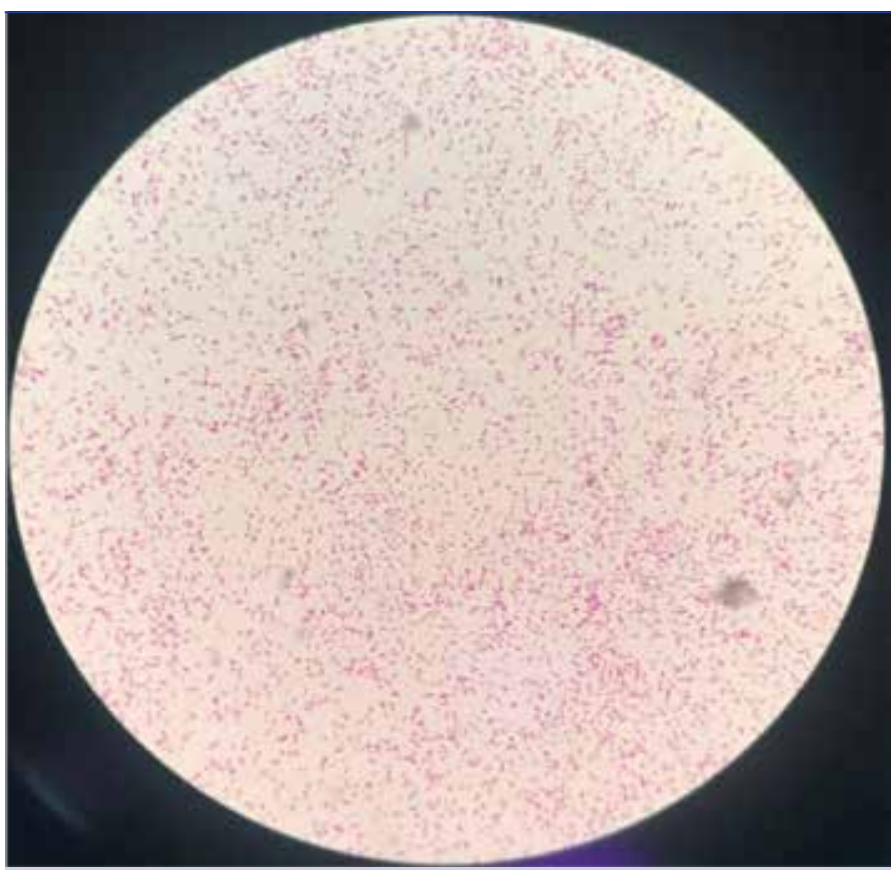

Figure 2. Gram staining of A.hydrophila

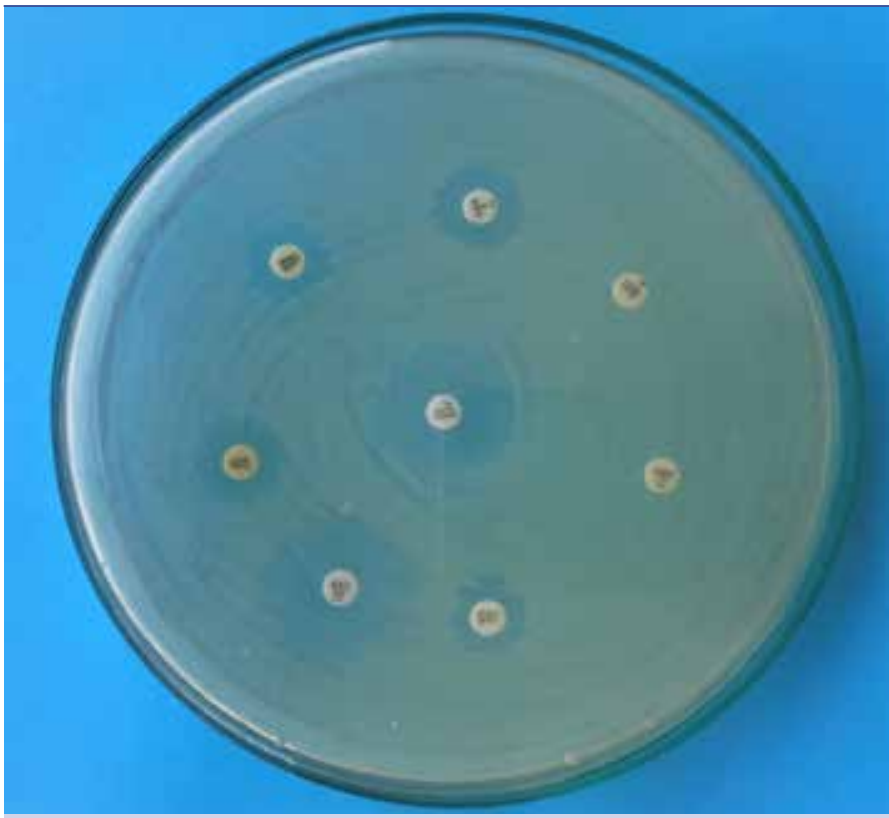

Figure 3. Antimicrobial susceptibility of A.hydrophila

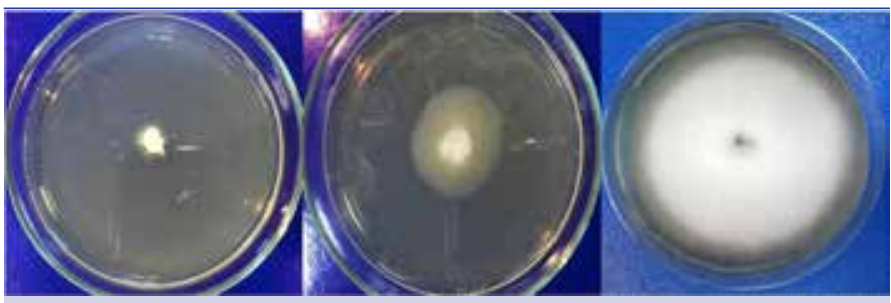

Figure 4. Fungal growth on SGA from skin samples of sea bass
Fungal growth was detected on SGA and MEA within 4 days of the samples being taken from mycelial growths on body surfaces (Figure 4). Long and branched hyphae with cysts were detected with a native and colored examination (Figure 5). Fungal zoospore was displayed from scanning electron microscopy overviews (Figure 6).

The PCR amplification of the 18S rRNA gene sequence was registered in the BLASTN 2.6.1 database. The FASTA homology showed $100 \%$ nucleotide identity between the current isolate and Saprolegnia parasitica (accession number AM228725.1).

Aeromonas hydrophila is a part of the normal intestinal microflora of healthy fish and stress is often a contributing factor (Yu et al., 2004). It is is an opportunistic pathogen (Arda et al., 2002) and effected by environmental factors such as oxygen, temperature, $\mathrm{pH}$ and stocking density (Klein and Wu, 1974). Like A.hydrophila, Saprolegnia spp. was reported from the natural environment of fish and, with suitable conditions, it is possible to be present as a secondary infection. Fish which are more vulnerable to physical conditions tend to be infected by Saprolegniosis (Neish and Huges, 1980; Diler, 1992). Saprolegniosis is considered as a secondary infection by Bruno et al. (2011) with immunosuppression, bacterial infections, poor husbandry and parasite infestations. The effect of this pathogen is reduced osmoregulation, which

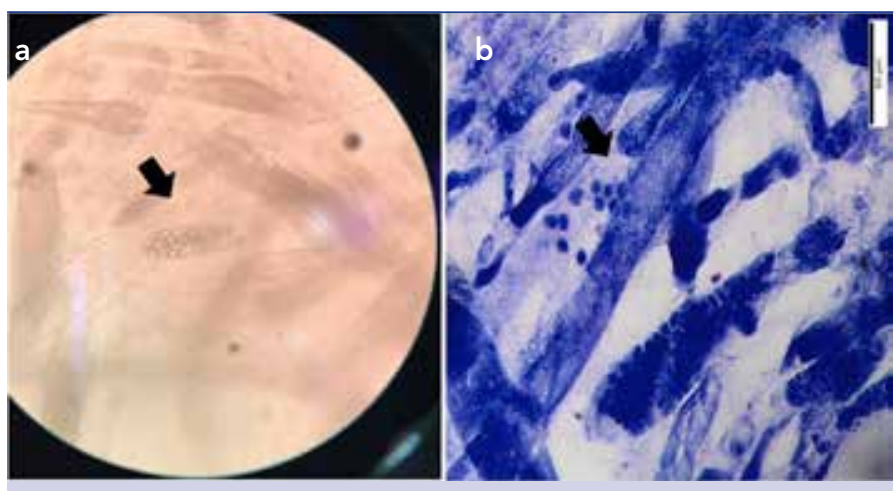

Figure 5. $a, b$.

(a) Zoosporangiums of S.parasitica $(x 40)(b)$ Giemsa staining view of zoosporangiums

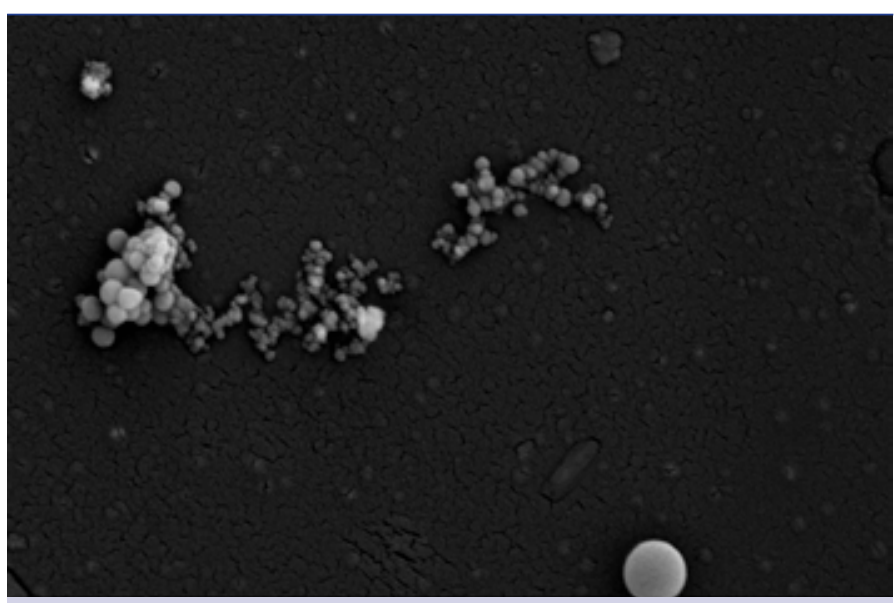

Figure 6. The zoospores of S.parasitica. SEM. Bar. $200 \mu \mathrm{m}$ scale 
Table 1. API 20 E results of isolated bacteria confirmed that the isolate was Aeromonas hydrophila

\begin{tabular}{lccc} 
ONPG & + & GLU & + \\
ADH & + & MAN & + \\
LDC & - & INO & - \\
ODC & - & SOR & + \\
CIT & - & RHA & - \\
H2S & + & SAC & + \\
URE & - & MEL & - \\
TDA & - & AMY & + \\
IND & + & ARA & + \\
VP & + & OX & + \\
GEL & + & & \\
\hline
\end{tabular}

Table 2. The antibiotic susceptibility test results of A. hydrophila

\begin{tabular}{lc}
\hline Antibiotic $\left(\mu \mathrm{g} \operatorname{disc}^{-1}\right)$ & \\
Ampicillin (10) & $\mathrm{R}$ \\
Enrofloxacin (5) & $\mathrm{I}$ \\
Florfenicol (30) & $\mathrm{I}$ \\
Oxytetracycline (30) & $\mathrm{I}$ \\
Amoxycillin (10) & $\mathrm{R}$ \\
Doxycycline (30) & $\mathrm{I}$ \\
Sulphamethoxazole/Trimethoprim (25) & $\mathrm{R}$ \\
Flumequine (30) & $\mathrm{I}$ \\
\hline R: Resistant, I: Intermediate, S: Sensitive & \\
\hline
\end{tabular}

Table 3. Water parameters during the infestation

\begin{tabular}{|c|c|c|c|}
\hline Temperature $\left({ }^{\circ} \mathrm{C}\right)$ & 10 & $\mathrm{NO}_{3}-\mathrm{N}(\mathrm{mg} / \mathrm{L})$ & 0.101 \\
\hline Salinity (\%o) & 3.93 & $\mathrm{NO}_{3}^{-}(\mathrm{mg} / \mathrm{L})$ & 0.461 \\
\hline Oxygen (mg/L) & 10.07 & $\mathrm{PO}_{4}^{-3}-\mathrm{P}(\mathrm{mg} / \mathrm{L})$ & 4.16 \\
\hline $\mathrm{pH}$ & 7.7 & 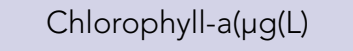 & 1.59 \\
\hline $\mathrm{NH}_{4}^{+}-\mathrm{N}(\mathrm{mg} / \mathrm{L})$ & 0.136 & $\mathrm{Ca}(\mathrm{mg} / \mathrm{L})$ & 280.54 \\
\hline $\mathrm{NH}_{4}^{+}(\mathrm{mg} / \mathrm{L})$ & 0.175 & $\mathrm{Mg}(\mathrm{mg} / \mathrm{L})$ & 272.23 \\
\hline $\mathrm{NO}_{2}-\mathrm{N}(\mathrm{mg} / \mathrm{L})$ & 0.0115 & Alkalinity $\left(\mathrm{CaCO}_{3} \mathrm{mg} / \mathrm{L}\right)$ & 338 \\
\hline $\mathrm{NO}_{2}-(\mathrm{mg} / \mathrm{L})$ & 0.0385 & Suspended solids & 2.25 \\
\hline $\mathrm{SiO}_{2}(\mathrm{mg} / \mathrm{L})$ & 6.45 & & \\
\hline
\end{tabular}

may even lead to death (Pickering and Willoughby, 1988). Kubilay et al. (2008) reported Saprolegnia spp. in rainbow trout fry infected with Flavobacterium columnare as a secondary opportunistic infection.

Aeromonas hydrophila has been reported in Salmo gairdneri (Peters et al., 1988), Carassius auratus (Citarasu et al., 2011), Oreochromis niloticus (Ibrahem et al., 2008), Clarias batrachus
(Angka, 1990), Cyprinus carpio (Citarasu et al., 2011) with skin lesions and hemorrhagic septicemia over the body, tail and fin regions (Sarder et al., 2016). It is generally considered to be a secondary invader (Rogers, 1971) like Saprolegniosis. Clinical symptoms of both pathogens were detected on D.labrax in this study. Similarly, hemorrhagic septicemia, tail or fin rot, changes on the body surface, fins, gills and tail because of fungus infection were reported in catfish (Clarias gariepinus) with the same clinical symptoms as this study (Kusdarwati et al.,2017) caused by A. hydrophila and Saprolegnia spp.

The water parameters during the outbreak arre shown in Table 3. Temperature, salinity, oxygen and $\mathrm{pH}$ parameters were determined as $10^{\circ} \mathrm{C}, 3.93 \%, 10.07 \mathrm{mg} / \mathrm{L}$ and 7.7 , respectively. Suspended solid was measured as $2.25 \mathrm{mg} / \mathrm{L}$ while the Ministry of Food, Agriculture and Livestock of the Turkish Republic determined maximum $2 \mathrm{mg} / \mathrm{L}$ for sea bass farming.

Aeromonas hydrophila infections are mostly found in warm waters but under stress conditions, it may cause infectionsdown to $5^{\circ} \mathrm{C}$. With a sudden increase of turbidity and a decrease in water temperature to $10^{\circ} \mathrm{C}$, Saprolegniasis and A.hydrophila were observed together in this case.

The antibiotic susceptibility tests were conducted from isolated A.hydrophila strains but after applying $200 \mathrm{~mL} /$ tone formol bath for 30 minutes everyday and revision of physical conditions, it was no longer necessary to apply antibiotics to infected fish.

The problems in the filtration unit of Izmir Katip Çelebi University Fisheries Research and Training Center caused water pollution and mortalities were observed, particularly in tanks which had high stocking density. The mortality rate was calculated to be $18 \%$ during that period. The sudden change of water quality and intensive fish stock may have caused this agent to show itself as hemorrhagic septicemia in this study. The primer pathogen could not be determined but after fixing the filtration system and formol bath, the infections were successfully treated. This result suggested that S.parasitica could be the dominant pathogen in this case.

\section{REFERENCES}

Abdel Aziz, E.S., Yonis, A.A., Ali., M.N.M. (2002). Effect of water temperature upon the response of cultured Clarias Lazera to Saprolegnia infection and the consequent haematologecal changes. Egyptian Journal of Compartive \& Clinical Pathology 15, No.2. pp. 108-125.

Akaylı, T., Zeybek, Z. (2005). Bazı Akvaryum Balıklarında Plesiomonas shigelloides Enfeksiyonu Üzerinde Bir Araştırma. Ege Üniversitesi Su Ürünleri Dergisi, 22(1-2), 31-34.

Angka, S.L. (1990). The pathology of the walking catfish Clarias batrachus (L.), infected intraperitoneally with Aeromonas hydrophila. Asian Fisheries Science 3, 343-351.

Arda, M. (2006). Temel mikrobiyoloji. Medisan Yayınevi, Ankara.

Arda, M., Seçer, S., Sarıeyyüpoğlu, M. (2002). Balık Hastalıkları. Medisan Yayınevi, Ankara. s, 142.

Austin B., Austin D.A. (2007). Bacterial Fish Pathogens, Disease of Farmed and Wild Fish, 4th Ed. Springer Praxis, Godalming.

Bakaletz, L.O. (2004). Developing animal models for polymicrobial diseases. Nat Rev Microbiol 2, 552-568. [CrossRef] 
Bangyeekhun, E., Pylkkö, P., Vennerström, P., Kuronen, H., Cerenius, L. (2003). Prevalence of a Single Fish-pathogenic Saprolegnia sp. Clone in Finland and Sweden. Diseases of Aquatic Organisms, 53(1), 4753. [CrossRef]

Bruno, D.W., van West, P., Beakes, G.W. (2011). Saprolegnia and other oomycetes In: Woo PTK, Bruno DW (eds). Fish Diseases and Disorders, Viral, Bacterial and Fungal Infections 2nd edn, Vol 3. CABI; Wallingford, UK, pp. 669-720. [CrossRef]

Cipriano R.C., Bullock G.L., Pyle S.W. (2001). Aeromonas hydrophila and Motile Aeromonad Septicemias of Fish. Fish Disease Leaflet 68, US Department of the Interior Fish \& Wildlife Service, Washington.

Citarasu, T., Alfred, D.K., Velmurugan, S., Thanga, V.V., Kumaran, T., Michael, B.M., Selvaraj, T. (2011). Isolation of Aeromonas hydrophila from infected ornamental fish hatchery during massive disease outbreak. International Journal of Current Research 2, 37-41.

Cox, F.E.G. (2001). Concomitant infections, parasites and immune responses. Parasitology 122:S23-S38 [CrossRef]

Diler, Ö. (1992). Saprolegniasis Hastalığının Patogenesisi ve Isparta Bölgesi Balık Işletmelerindeki Dağılımı Üzerinde Bir Araştırma. A. Ü. Fen Bilimleri Enstitüsü, Doktora Tezi, 117s.

Diler, Ö., Altun, S. (1995). Gökkuşağı Alabalıklarında (Oncorhynchus mykiss) Hemorajik Septisemi Etkeni Olarak izole Edilen Bazı Aeromonas hydrophila Suslarının Biyokimyasal Özelliklerinin Belirlenmesi, Süleyman Demirel Üniversitesi Su Ürünleri Mühendislik Dergisi 4, 169-178.

Egemen, Ö., Sunlu, U. (2003). Su Kalitesi. Ege Üniversitesi Basımevi, İzmir. Gaikowski, M. P., Rach, J. J., Drobish, M., Hamilton, J., Harder, T., Lee, L. A., Moen, C., Moore, A. (2003). Efficacy of hydrogen peroxide in controlling mortality associated with saprolegniasis on walleye, white sucker, and paddlefish eggs. North American Journal of Aquaculture 65(4), 349-355. [CrossRef]

Hudzicki, J. (2009). Kirby-Bauer disk diffusion susceptibility test protocol. American Society for Microbiology 1-14.

Huizinga H.W., Esch, G.W., Hazen, T.C. (1979). Histopathology of RedSore Disease (Aeromonas hydrophila) in Naturally and Experimentally Infected Largemouth Bass Micropterus salmoides (Lacepede). Journal of Fish Diseases 2, 263-277. [CrossRef]

Hussien, A. M., Ahmed, I. E., Waled, S. E., Omima, A. (2010). A trial for Induction of Saprolegniosis in Mugel cephalus with Special Reference to Biological Control. Journal of American Science, 6(6), 6.

Ibrahem, M.D., Mostafa, M.M., Arab, R.M.H., Rezk, M.A. (2008). Prevalence of Aeromonas hydrophila infection in wild and cultured tilapia nilotica (O. niloticus) in Egypt. Elghobashy H, Fitzsimmons K, Diab AS (eds.). Proceedings of 8th International Symposium on Tilapia in Aquaculture, Cairo, Egypt, 12-14 Oct 2008. Vol. 2. pp. 1257-1270.

Klein, D., Wu, S. (1974). Stress. A Factor to be Considered in Heterotrophic Microorganism Enumeration From Aquatic Environments. Applied Microbiology, 27(2), 429-431.

Kotob, M. H., Menanteau-Ledouble, S., Kumar, G., Abdelzaher, M., El-Matbouli, M. (2016). The impact of co-infections on fish: a review. Veterinary Research, 47(1), 98. [CrossRef]

Kubilay, A., Altun, S., Diler, Ö., Ekici, S. (2008). Isolation of Flavobacterium columnare from Cultured Rainbow Trout (Oncorhynchus mykiss) fry in Turkey. Turkish Journal of Fisheries and Aquatic Sciences, 8(1), 165-169.

Kusdarwati, R., Kismiyati, Sudarno, Kurniawan H., Prayogi, Y.T. (2017). Isolation and Identification of Aeromonas hydrophila and Saprolegnia sp. on Catfish (Clarias gariepinus) in Floating cages in Bozem Moro Krembangan Surabaya. IOP Conf. Ser.: Earth Environ. Sci. 55012038.

Laith, A.R., Najiah, M. (2013). Aeromonas hydrophila: Antimicrobial Susceptibility and Histopathology of Isolates from Diseased Catfish, Clarias gariepinus (Burchell). Journal of Aquaculture Research and Development, 5, 215.
Lukistyowati, I. (2012). Pelacakan Gen Aerolysin dari Aeromonas hydrophila pada Ikan Mas yang Diberi Pakan Ekstrak Bawang Putih (Detection of Aerolysin Gen orom Aeromonas hydrophila In Common Carp Fed With Garlic Extract). Jurnal Veteriner, 13(1), 43-50.

Neish, G. A., Hughes, G. C. (1980). Diseases of Fishes Book 6. Fungal Diseases of Fishes. T. W. F. Publications, Neptune, pp. 159, New Jersey.

Noga E.J. (1993). Water Mold Infections of Freshwater Fish: Recent Advances. Annual Review of Fish Diseases 3, 291-304 [CrossRef]

Osman, H.A.M., Solman, W.E., Noor El Deen, A.E., Lada, A.M. (2008). Induction of Saprolegniosis in Oreochromis niloticus with Special Reference to its Biological. Control. Global Veterinaria 2(1), 32-37.

Parsons, T.R., Matia, Y., Lalli, C.M. (1984). A manual of chemical and biological methods for sea water analysis, New York: Pergamon Press, p.173.

Peters, G., Faisal, M., Lang, T., Ahmed, I. (1988). Stress caused by social interaction and its effect on susceptibility to Aeromonas hydrophila infection in rainbow trout Salmo gairdneri. Disease of Aquatic Organisms 4: 83-89. [CrossRef]

Pickering, A.D., Willoughby, L.G. (1988). Saprolegnia of Salmonid Fish. 15th Annual Report, U.S. Fish and Wildlife Service. pp.38-48.

Pickering, A.D. (1994). Factors Which Predispose Salmonid Fish to Saprolegniasis. Edited by G. J. Mueller. U.S. Department of Energy, Bonneville Power Administration, Portland, Oregon, 1994, pp.67-84.

Rey, G., Fouillet, A., Bessemoulin, P., Frayssinet, P., Dufour A. (2009). Heat Exposure and Socio-Economic Vulnerability as Synergistic Factors in Heat- Wave-Related Mortality. European Journal of Epidemiology 24: 495-502. [CrossRef]

Roberts, R.J., Shepherd, C. J. (2001). Alabalık ve Salmon Hastalıkları (Handbook of Trout and Salmon Diseases), (Çevirmen: Vatansever, H.). Akademi-UĞURER Tarımsal Kitap Tanıtım ve Pazarlama Hizmetleri, Kayseri, s.254.

Roberts, R.J. (2012). Fish Pathology, 4.Edition. Blackwell Publishing, United Kingdom, pp.387-390. [CrossRef]

Rogers, W.A. (1971). Disease in fish due to the protozoan Epistylis (Ciliata: Peritricha) in the southeastern U.S. Proc. 25th Ann. Conf. Southeastern Assoc. Game Fish Commis- sioners, pp. 493-496.

Sarder, H., Khan, T., Saha, M. L., Punom, N. J., Mandal, S.C., Rahman, M.S. (2016). Prevalence and antibiotic susceptibility of Aeromonas hydrophila isolated from freshwater fishes. Journal of Fisheries, 4(3), 411-419. [CrossRef]

Stirling, H.P. (1985). Chemical and Biological Methods of Water Analysis for Aquaculturalists. Institute of Aquaculture, University of Stirling, $119 \mathrm{p}$.

Strickl, J.D.H., Parsons, T.R. (1972). A Practical Handbook of Seawater Analysis, 2nd ed. Bulletin, vol 167 Ottowa: Fisheries Research Board of Canada, $310 \mathrm{p}$.

Tanrıkul, T.T., Cagirgan, H., Toksen, E. (2004). Levreklerden (Dicentrarchus labrax I., 1758) izole edilen vibrio türlerinin API 20 E yöntemiyle identifikasyonu. Ege Üniversitesi Su Ürünleri Dergisi, 2004, 243-247.

Timur, M. (1986). Aynalı Sazan (Cyprinus carpio L.) ve Japon Balıklarında (Carassius auratus) Görülen Bakteriyel Hemorajik Septisemi Hastalığı Üzerinde Karşılaştırmalı Bir Araştırma. Ege Üniversitesi Su Ürünleri Su Ürünleri Dergisi, 3, 95-105.

Timur, G., Korun J., Güvener, R.P. (2003). Lepistes (Poecillia reticulata) Üretim Ünitesindeki Anaç Ve Yavru Balıklarda Agır Mortalite Ile Seyreden Aeromonad Septisemi Üzerine Bir Çalışma, İstanbul Üniversitesi Su Ürünleri Dergisi, 15, 1-11.

Yu, H.B., Rao, P.S.S., Lee, H.C., Vilches, S., Merino, S. (2004). A Type III Secretion System is Required for Aeromonas hydrophila AH-1 Pathogenesis. Infect Immun, 72: 1248-1256. [CrossRef] 